\title{
UNREAL DISTINCTIONS: THE EXCLUSION OF UNFAIRLY OBTAINED EVIDENCE UNDER S. 24(2) OF THE CHARTER
}

\section{STEVEN M. PENNEY}

This article begins with an examination of the historical treatment of illegally obtained evidence in common law jurisdictions outside of Canada. PreCharter Canadian law, as well as pre-Charter commentary and proposals for reform are also discussed.

The article then examines post-Charter jurisprudence in Canada, exploring the problems and inconsistencies in the courts' interpretation of section 24(2). The author suggests that the distinction between real/self-incriminatory evidence as a basis for exclusion is philosophically and practically flawed, and should be abandoned in favour of an approach which considers the "discoverability" of the evidence in question.

\begin{abstract}
L'auteur commence par examiner le traitement de la preuve obtenue illégalement dans les juridictions de common law extérieures au Canada. Le droit canadien d'avant la Charte est également examiné, ainsi que les commentaires et propositions de réforme.

Le présent article discute aussi de la jurisprudence canadienne qui a fait suite à la Charte et relève cerlains problèmes et inconsistances dans l'interprétation de l'article 24(2). L'auteur suggère que la distinction entre la preuve matérielle et renfermant une incrimination de soi-même comme motif d'exclusion fait problème sur le plan philosophique et pratique, et qu'elle devrait ètre abandonnée en faveur d'une approche qui tiendrait compte de l'accessibilité ou du caractère "découvrable» des éléments de preuve en question.
\end{abstract}

\section{TABLE OF CONTENTS}

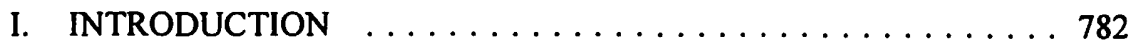

II. HISTORICAL AND COMPARATIVE CONTEXT $\ldots \ldots \ldots \ldots 784$

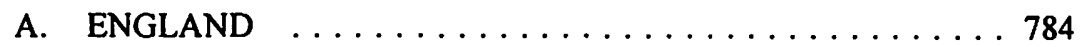

B. THE UNITED STATES $\ldots \ldots \ldots \ldots \ldots \ldots \ldots \ldots .788$

C. OTHER COMMON LAW JURISDICTIONS $\ldots \ldots \ldots \ldots 790$

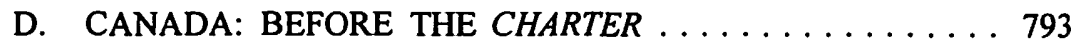

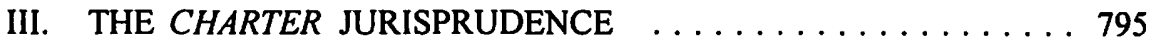

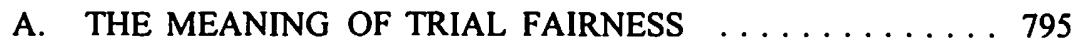

B. WHAT KIND OF EVIDENCE AFFECTS

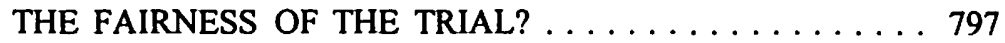

C. REAL EVIDENCE AND TRIAL FAIRNESS $\ldots \ldots \ldots \ldots 802$

D. ADMISSION NOTWITHSTANDING

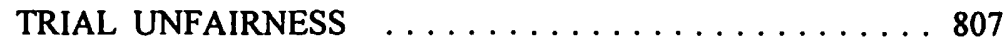

VI. CONCLUSIONS $\ldots \ldots \ldots \ldots \ldots \ldots \ldots \ldots \ldots \ldots \ldots$

\section{INTRODUCTION}

The exclusion of illegally obtained evidence at a criminal trial is a thoroughly modern phenomenon. At common law, relevant evidence was admissible no matter how it was obtained. Courts were primarily concerned with ensuring the trustworthiness of

LL.B., University of Alberta, 1994. The author wishes to thank Bruce Elman and David Schneiderman for their helpful comments on earlier drafts of this article. This article won first prize in the 1994 William Morrow essay contest. 
evidence proffered at trial, and were not interested in extending their authority over the investigative component of the criminal justice system. In the years following the Second World War, most common law jurisdictions have moved away from this position. In Canada, the traditional inclusionary rule remained firmly ensconced until the constitutional entrenchment of the Canadian Charter of Rights and Freedoms ${ }^{1}$ in 1982. The Charter guarantees certain fundamental legal rights, and section 24(2) empowers courts to exclude evidence obtained in violation of those rights. ${ }^{2}$

Courts and commentators, however, are unanimous in the view that section 24(2) does not set out a rule of automatic exclusion. Rather, in accordance with the language of the provision, evidence is to be excluded only where "it is established that, having regard to all the circumstances, the admission of it in the proceedings would bring the administration of justice into disrepute." In $R$. v. Collins, ${ }^{3}$ the Supreme Court of Canada elucidated a number of factors that courts should look to in determining whether the circumstances of the case are such that the admission of the illegally obtained evidence would bring the administration of justice into disrepute. Foremost among these is whether or not the admission of the evidence would affect the "fairness of the trial." ${ }^{14}$ Such evidence, which will usually take the form of an incriminatory statement or other evidence conscripted from the accused, will almost always be excluded. The admission of "real evidence", on the other hand, which exists irrespective of the violation of the Charter, is generally not considered to operate unfairly to the accused. $^{5}$ This kind of evidence will be excluded only if the infringement of the Charter right is so serious that the admission of the evidence would constitute judicial condonation of unacceptable police conduct. ${ }^{6}$

Part I of the Constitution Act, 1982, being Schedule B to the Canada Act 1982 (U.K.), 1982, c.11 [hereinafter Charler] (all citations to C.R. unless otherwise noted).

Section 24 of the Charler states:

(1) Anyone whose rights or freedoms, as guaranteed by this Charter, have been infringed or denied may apply to a court of competent jurisdiction to obtain such remedy as the court considers appropriate and just in the circumstances.

(2) Where, in proceedings under subsection (1), a court concludes that evidence was obtained in a manner that infringed or denied any rights or freedoms guaranteed by this Charter, the evidence shall be excluded if it is established that, having regard to all the circumstances, the admission of it in the proceedings would bring the administration of justice into disrepute.

The language of section 24 has been interpreted in considerable detail by the courts. This essay is primarily concerned with the "circumstances" which may bring the administration of justice into disrepute. For a thorough discussion of the other issues that section $24(2)$ engenders, readers are encouraged to consult K. Jobson, "The Canadian Charter of Rights and Freedoms: Section 24(2)" in W.H. Charles et al., Evidence and the Charter of Rights and Freedoms (Toronto: Butterworths, 1989) 199 at 219-347. For a more concise and up-to-date overview see D. Stuart, Charter Justice in Canadian Criminal Law (Scarborough: Carswell, 1991) at 385-95. 56 C.R. (3d) 193, 33 C.C.C. (3d) 1, [1987] I S.C.R. 265 [hereinafter Collins].

Ibid. at 211.

Ibid.

Ibid. at 212. 
Though this conceptual distinction between real and conscriptive evidence has been subjected to criticism, it has remained the cornerstone of the Supreme Court's approach to section 24(2). The Court's decision as to whether the evidence will affect the fairness of the trial will often be determinative of the exclusion question. This article represents an attempt to disassemble this schema: to understand its philosophical underpinnings, to uncover its genealogy and to evaluate its appropriateness in light of the purposes of the Charter and of the criminal justice system.

In order to provide an historical and comparative context for the Supreme Court's approach to trial fairness, in Part II of this article I examine the treatment of illegally obtained evidence in other common law jurisdictions. The pre-Charter Canadian law is also discussed, as are the various suggestions for reform that were made in Canada before the adoption of the Charter. Part III explores in some detail the section 24(2) jurisprudence of the Supreme Court. I discuss the Court's conception of trial fairness and the problems and inconsistencies inherent in the real/self-incriminatory evidence distinction. I suggest that the distinction is philosophically and practically flawed, and that it should be abandoned in favour of an approach which considers the "discoverability" of the evidence in question. I also advance the view that it is inappropriate to exclude evidence obtained unfairly more readily than evidence acquired from the infringement of privacy interests. In conclusion, I speculate that the Supreme Court's approach to the fairness issue stems from the Court's reluctance, even in the era of the Charter, to embrace an expansive, supervisory role over the entire criminal justice process.

\section{HISTORICAL AND COMPARATIVE CONTEXT}

\section{A. ENGLAND}

During the nineteenth century, English courts paid scant attention to the question of excluding illegally obtained evidence. ${ }^{7}$ As the method of obtaining evidence was considered to be irrelevant to its admissibility, there was little reason to comment on the issue. ${ }^{8}$ The sole exception to this rule was the long-established discretion to exclude confessions obtained by threat, coercion or improper inducements. ${ }^{9}$ Such evidence was inadmissible not simply because it was improperly obtained. Rather, it was excluded on the basis that the manner of its acquisition called into question its trustworthiness. ${ }^{10}$ The admission of unreliable evidence, it was thought, would unduly

7 See M.S. Weinberg, "The Judicial Discretion to Exclude Relevant Evidence" (1975) 21 McGill L.J. 1 at 13.

$8 \quad$ Ibid. One exception was $R$. v. Leatham (1861), 8 Cox C.C. 498 at 13, 121 Eng. Rep. 589 (Q.B.), where Justice Crompton declared bluntly that "it matters not how you get it; if you steal it even, it would be admissible in evidence."

, See W. Baldiga, "Excluding Evidence to Protect Rights: Principles Underlying the Exclusionary Rule in England and the United States" (1983) 6 Boston College Int'l. \& Comp. L. Rev. 133 at 136.

10 This rationale for the confession rule was first articulated in $R$. v. Warickshall (1783), 1 Leach 263, 168 E.R. 234 at 235 (Cr. Cas. Res.), where Justice Nares held that "a confession forced from the mind by the flattery of hope, or by the torture of fear, comes in so questionable a shape when 
prejudice the trier of fact. In the early part of this century, English courts developed a general discretion to exclude where the probative value of the evidence was outweighed by its prejudicial effect." The fact that such evidence might have been obtained illegally, however, was not a basis for its exclusion.

It was not until the Privy Council's decision in Kuruma v. The Queen ${ }^{12}$ that an appellate court intimated that there might be a discretion to exclude evidence based solely on the manner in which it was obtained. In that case a police officer conducted an illegal search of the defendant Kuruma in what was at that time the British colony of Kenya. The search revealed that Kuruma was carrying ammunition in violation of wartime emergency regulations. ${ }^{13}$ In deciding to admit the evidence, the Committee restated the rule that evidence is admissible no matter how it was obtained. However, Lord Goddard, who delivered the reasons of the Court, went on to make a curious comment:

No doubt in a criminal case the judge always has a discretion to disallow evidence if the strict rules of admissibility would operate unfairly against an accused. This was emphasized in the case before this

it is to be considered as the evidence of guilt, that no credit ought to be given to it; and therefore it is rejected." The modern form of the confession rule was enunciated in Ibrahim v. $R$, [1914] A.C. 599, [1914-15] All E.R. Rep. 847 (P.C.). For a comprehensive review of the history of the confession rule see P. Mirfield, Confessions (London: Sweet \& Maxwell, 1985) at 42-60. Evidence of the accused's bad character is often excluded on this basis. For example, see $R$. v. Watson (1913), 8 Crim. App. 249. The general rule is that the Crown is prohibited from adducing evidence of the accused's character unless the accused has put character in issue or the evidence is otherwise relevant to a specific issue. Evidence of similar past acts of the accused, for example, will only be admitted if it is relevant to a specific issue and its probative value outweighs the prejudice to the accused that might arise from admission. For example, see Noor Mohamed $v$. $R$, [1949] A.C. 182 (P.C.) (Brit. Guiana) [hereinafter Noor Mohamed]. For a general discussion of character and similar fact evidence see J. Sopinka et al., The Law of Evidence in Canada (Toronto: Butterworths, 1992) at 454-55, 477.

[1955] A.C. 197, [1955] 1 All E.R. 236 (P.C.) [hereinafter Kuruma]. In $R$ v. Barker, [1941] 2 K.B. 381 [hereinafter Barker], the Court excluded documentary evidence which had been obtained by making a false promise of immunity. Although the Court did not clearly state the grounds for exclusion, it referred to the confession cases in support of its decision. However, the basis for exclusion clearly could not have been reliability or undue prejudice.

These regulations were promulgated in the face of the infamous Kikuyu or "Mau-Mau" rebellion of 1951-55. In response to a series of attacks made by dispossessed Kikuyu on British settlers, the colonial authorities initiated a rather brutal counter-terrorist program, which included the use of coercive interrogations, detention camps and forced expulsions. See R. Oliver \& A. Atmore, Africa Since 1800, 3d ed. (Cambridge: Cambridge University Press, 1981) at 257-60; B. Freund, The Making of Contemporary Africa: The Development of African Society Since 1800 (Bloomington: Indiana University Press, 1984) at 218-19. In the context of this widespread repression, the facts of the Kuruma case take on a disturbing quality. At trial, Kuruma denied that he had been in possession of ammunition. It was also revealed that Kuruma knew of the roadblock that had been set up and could have easily avoided the search. Third party witnesses to the incident did not testify and some of the evidence found in the search allegedly disappeared and was never produced at trial. The trial court nevertheless convicted Kuruma and sentenced him to death. The Privy Council upheld the conviction, but stated that "there were matters of fact in the case which caused them some uneasiness" and recommended that the Secretary of State consider the case before carrying out the mandatory death sentence; ibid. at 205. See J.D. Heydon, "Illegally Obtained Evidence (1)" (1973) Crim. L. Rev. 603 at 606-07. 
Board of Noor Mohamed v. The King, and in the recent case in the House of Lords, Harris v. Director of Public Prosecutions. If, for instance, some admission of some piece of evidence, e.g. a document, had been obtained from a defendant by a trick, no doubt the judge might properly rule it out. ${ }^{14}$

As Noor Mohamed ${ }^{15}$ and Harris ${ }^{16}$ were both cases involving the exclusion of similar fact evidence, it might at first appear that Lord Goddard was merely restating the wellestablished discretion to exclude prejudicial evidence. ${ }^{17}$ His use of the document example, however, illustrated a situation where probative evidence might be excluded because of the method in which it was obtained, not because it might be unduly prejudicial or unreliable.

Unfortunately, Lord Goddard's dictum created much confusion. Some commentators interpreted it as merely confirming the exclusion of improperly obtained confessions on the reliability principle. ${ }^{18} \mathrm{~A}$ number of English courts, in contrast, viewed the case as endorsing a general discretion to exclude unfairly obtained evidence. ${ }^{19}$ However, few of the courts that recognized the discretion actually invoked it, and in none of the decisions was there a clear explication of the rationale for the discretion or the manner in which it was to be exercised. ${ }^{20}$

In $R$ v. Sang, ${ }^{21}$ the House of Lords set out to resolve this ambiguity. The Court took

14

is

16

17

Ibid. at 203.

Supra note 11.

[1952] A.C. 182 (P.C.).

Baldiga, supra note 9 at 137.

See J.A. Andrews, "Involuntary Confessions and Illegally Obtained Evidence in Criminal Cases: I" [1963] Crim. L. Rev. 15. This was also the interpretation taken of Kuruma in the Supreme Court of Canada's decision in $R$ v. Wray. See infra notes 70-76 and accompanying text.

See $R$. v. Court, [1962] Crim. L.R. 697 [hereinafter Court]; $R$ v. Payne, [1963] 1 W.L.R. 637 (C.C.A.) [hereinafter Payne]; Callis v. Gunn, [1964] 1 Q.B. 495 [hereinafter Callis]; Jeffery v. Black, [1978] I Q.B. 490 [herinafter Jeffery].

In Payne and Court, the Court of Criminal Appeal excluded the evidence of an examining doctor which was obtained on the representation that the doctor would not make any determination as to the defendant's fitness to drive. Had the defendants been informed of the true consequences of submitting to the examination, the Court reasoned, they would not likely have done so (ibid.). In Callis, the Court of Queen's Bench overturned the decision of the trial judge to exclude fingerprint evidence obtained without authorization and without informing the defendant of either his right to refuse or that the fingerprints might be used as evidence against him. Chief Justice Parker considered that the discretion outlined in Kuruma could only be exercised where the police acted "in an oppressive manner by force or against the wishes of an accused" or where the evidence was obtained "oppressively, by false representations, by a trick, by threats, by bribes, anything of that sort." Ibid. at 501-02. Similarly, in Jeffery, the Court of Queen's Bench overturned the trial justices' decision to exclude evidence of narcotics which had been obtained from an unauthorized search. The Court held that the discretion to exclude is available if the police "have been guilty of trickery or they have misled someone, or they have been oppressive or they have been unfair, or in other respects they have behaved in a manner which is morally reprehensible." Ibid. at 498. [1980] A.C. 402 (H.L.) [hereinafter Sang]. Although Sang was decided on the basis that the defence of entrapment did not exist in English law, and that there was no discretion to exclude evidence obtained through entrapment, the Court of Appeal certified a much broader question for consideration by the House: "Does a trial judge have a discretion to refuse to allow evidence-being evidence other than evidence of admission-to be given in any circumstances in which such evidence is relevant and of more than minimal probative value?" Lord Diplock urged his fellow 
a narrow view of the Kuruma case and declared that the Privy Council had not intended to acknowledge a general discretion to exclude wrongfully obtained evidence. ${ }^{22}$ The Law Lords concurred with Lord Diplock's declaration that a trial judge only has a discretion to exclude relevant, non-prejudicial evidence if it relates to a confession, admission or evidence "obtained from the accused after the commission of the offence. ${ }^{23}$ According to Lord Diplock, evidence "obtained from the accused" refers to "evidence tantamount to a self-incriminatory admission which was obtained from the defendant, after the offence had been committed, by means which would justify a judge in excluding an actual confession which had the like self-incriminating effect." 24 Clearly, the basis for exclusion in these circumstances could not be reliability. Lord Diplock acknowledged this, and proclaimed that the foundation of the discretion to exclude both incriminating statements and evidence "obtained from the defendant" was the right to silence. He stated:

The underlying rationale of this branch of the criminal law, though it may originally have been based upon ensuring the reliability of confessions is, in my view, now to be found in the maxim nemo debet prodere se ipsum, no one can be required to be his own betrayer or in its popular English mistranslation "the right to silence." That is why there is no discretion to exclude evidence discovered as the result of an illegal search but there is discretion to exclude evidence which the accused has been induced to produce voluntarily if the method of inducement was unfair. ${ }^{25}$

It is important to note that while each of the Lords expressed broad concurrence with the speech of Lord Diplock, a close reading reveals that they did not necessarily agree with his formulation of the nature or scope of the discretion. Lord Diplock and Viscount Dilhorne considered that the fairness of the trial was not affected by the unfairness of the methods used to obtain the evidence. They asserted that the discretion to exclude confession evidence and its analogues is based on the right to silence, not trial fairness, and constitutes an exception to the principle that the judge should be exclusively concerned with the reliability of evidence adduced at trial. ${ }^{26}$ The remaining Law Lords viewed the fairness of the trial in much broader terms. They considered the discretion, and the right to silence upon which it is grounded, as an instantiation of the trial fairness principle. None of them, however, explained why some kinds of "unfair"

Lords to give the question full consideration in order to resolve the uncertainty which was plaguing this area of the law. Ibid. at 431-2. Strictly speaking then, the Law Lords' pronouncements on this question are obiter dicta.

Ibid. at 436.

Ibid. at 437.

Ibid. at 436. Lord Diplock was thus able to justify the exclusion of evidence in the Barker and Payne decisions, supra notes 12 and 19 . In both cases, the police illegally obtained the evidence from the defendant himself. In Barker, the police used an unfair trick to obtain an incriminating document, and in Payne the police deceived the defendant into submitting to a medical examination later used in evidence against him.

lbid. While it seems clear that this discretion would not generally allow for the exclusion of real evidence obtained as a result of an illegal search, it may be that real evidence derived from an unfairly induced confession could be excluded. See A. McLellan \& B. Elman, "The Enforcement of the Canadian Charter of Rights and Freedoms: An Analysis of Section 24" (1983) 21 Alta. L. Rev. 205 at 230, n. 119. 
treatment might trigger the power to exclude while others do not. They were accordingly reluctant to limit the circumstances in which the trial judge might properly exclude evidence in order to preserve the fairness of the trial. ${ }^{27}$

While the precise scope of the discretion outlined in Sang remains unclear, it is apparent that it will be exercised only in exceptional circumstances. In $R$. v. Apicella ${ }^{28}$ for example, the Court of Appeal refused to exclude medical evidence obtained from the accused for therapeutic reasons. The Court reasoned that as the defendant had not been tricked into submitting to the procedure, the use of the evidence at trial was not unfair.

In 1984, the English Parliament passed the Police and Criminal Evidence Act. ${ }^{29}$ The Act preserved the common law discretion ${ }^{30}$ and added a new statutory discretion to exclude evidence which would adversely affect the fairness of the trial. ${ }^{31}$ This new discretionary power has been interpreted to be wider than the common law discretion, and evidence has been excluded in a much broader range of circumstances than was the case under the common law. ${ }^{32}$ In accordance with the language of the provision, however, the discretion will only be exercised where police impropriety affects the fairness of the proceedings. ${ }^{33}$ Consequently, illegal conduct by investigating authorities, no matter how egregious or reprehensible, will not result in the exclusion of evidence unless the admission of that evidence would compromise the accused's privilege against self-incrimination. ${ }^{34}$

\section{B. THE UNITED STATES}

At common law, the American position on the exclusion of illegally obtained evidence was the same as that in England: "the admissibility of the evidence is not affected by the illegality of the means through which the party has obtained the

Ibid. at 444-45 (per Lord Salmon), at 449-50 (per Lord Fraser) and at 454-455 (per Lord Scarman).

28 (1985) 82 Cr. App. R. 295.

$29 \quad 1984$ (U.K.), c. 60.

so Ibid. ss. 78(2) and 82(3).

$31 \quad$ Ibid. s. 78(1). The provision states:

In any proceedings the court may refuse to allow evidence on which the prosecution proposes to rely to be given if it appears to the court that, having regard to all the circumstances, including the circumstances in which the evidence was obtained, the admission of the evidence would have such an adverse effect on the faimess of the proceedings that the court ought not to admit it.

See M. Zander, The Police and Criminal Evidence Act 1984, Rev. 2d ed. (London: Sweet \& Maxwell, 1990) at 201-205.

31 See R. May, Criminal Evidence, 2d ed. (London: Sweet \& Maxwell, 1990) at 239-40.

34 Ibid. at 238. In R. v. Samuel, [1988] Q.B. 615, (1987) 87 Cr. App. R. 232, [1988] 2 W.L.R. 920

(C.A.), for example, the Trial Court admitted evidence of a confession made after the accused had been refused access to a solicitor in violation of the Act. The Court of Appeal held that had the accused been accorded access to counsel, the incriminating statement would not likely have been made. As a result, the statement should have been excluded. 
evidence. ${ }^{135}$ What we think of today as the exclusionary rule developed gradually over the course of this century in response to evolving interpretations of the Bill of Rights provisions of the U.S. Constitution. In Weeks v. U.S., the Supreme Court held that property seized in violation of the Fourth Amendment right to be secure against unreasonable search and seizure could not be used in a federal prosecution against the objections of the accused. ${ }^{36}$ In subsequent decisions, the ambit of the rule was expanded to include other forms of seized evidence, including evidence derived from the initial violation. ${ }^{37}$ The exclusionary rule was also eventually applied to evidence obtained in violation of the Fifth and Sixth Amendment rights to silence and counsel. ${ }^{38}$ Finally, in Mapp v. Ohio ${ }^{39}$ and Schmerber v. California ${ }^{40}$ the Supreme Court determined that the due process provision of the Fourteenth Amendment mandated that evidence obtained in violation of any of these constitutional rights also be excluded in state prosecutions.

Since the American exclusionary rule is generally characterized as operating automatically, its analogical utility is often discounted by Canadian courts and commentators. The American experience may be instructive, however, in at least two respects. First, it is clear that the exclusionary principle does not discriminate between real and self-incriminatory evidence. In Miranda v. Arizona, ${ }^{41}$ the Supreme Court decided that in addition to passing the voluntariness test, confessions would have to withstand the scrutiny of the self-incrimination privilege guaranteed by the Fifth Amendment. ${ }^{42}$ If these guidelines are not adhered to, the resulting confession will be excluded. Real evidence, whether obtained directly as a result of a search or derived from a confession, is similarly inadmissible. ${ }^{43}$ In either case, the court focuses its inquiry on the constitutional right that has allegedly been violated, not on the nature of the evidence that is sought to be admitted. ${ }^{44}$

Second, the exceptions to the exclusionary rule that have been developed by U.S. courts may be relevant to the exclusion of evidence under section 24(2) of the Charter. Three of these exceptions will be briefly related here. ${ }^{45}$ The independent source doctrine provides for the admission of evidence despite police illegality if the evidence

J.H. Wigmore, Evidence in Trials at Common Law, vol. 8, revised by J.T. McNaughton (Boston: Little, Brown \& Co., 1961) at $7, \S 2183$.

232 U.S. 383,34 S.Ct. 341 (1914).

Silverthorne Lumber v. U.S., 251 U.S. 385 (1920) [hereinafter Silverthome]; Nardone v. U.S., 308 U.S. 338 (1939).

Wong Sun v. U.S., 371 U.S. 471 (1963) [hereinafter Wong Sun].

367 U.S. 643 (1961) [hereinafter Mapp].

384 U.S. 757, 86 S.Ct. 1826 (1966).

384 U.S. 436, 86 S.Ct. 1602 (1966).

The Court imposed the now famous requirement that a warning be given to the accused informing him of his right to remain silent and to request the assistance of counsel, and alerting him to the fact that any statements he might make could be used against him.

Mapp, supra note 39; Wong Sun, supra note 38.

See J. Klotter, Criminal Evidence, 4th ed. (Cincinnati: Anderson, 1987) at 332-53.

For a full discussion of the various exceptions to the exclusionary principle see M. Meegan, "The Exclusionary Rulen (21st Annual Review of Criminal Procedure: United States Supreme Court and Courts of Appeals 1990-1991) (1992) 80 Georgetown L.J. 1096. 
was recovered through a source independent of the illegal activity ${ }^{46}$ Closely related is the inevitable discovery exception, which allows a court to admit illegally obtained evidence if the evidence would have inevitably been discovered through independent, lawful means. ${ }^{47}$ Lastly, the harmless error doctrine states that illegally obtained evidence may be admitted if the government establishes beyond a reasonable doubt that admission could not have contributed to the defendant's conviction. ${ }^{48}$ This exception applies to violations of Fourth, ${ }^{49}$ Fifth $^{50}$ and Sixth Amendment ${ }^{51}$ rights as well as to involuntary confessions. ${ }^{52}$ Each of these exceptions seems to be founded on the notion that while the state should not profit from its own wrongdoing, it also should not be placed in a worse position than it would have been in had no illegality taken place.

\section{OTHER COMMON LAW JURISDICTIONS}

A number of other common law jurisdictions have followed a course which departs from both the English and American positions. In Scotland, Australia, Ireland and New Zealand, courts are empowered with a general discretion to exclude illegally obtained evidence. As is the case for section 24(2) determinations, the exercise of this discretion involves a balancing of competing policy interests: the state's interest in controlling crime and the individual's interest in being free from intrusive and unfair treatment by state authorities. ${ }^{53}$ The principles that courts in these jurisdictions have developed to

\section{Silverthorne, supra note 37.}

Nix v. Williams, 467 U.S. 431 (1984). In this case the police elicited statements from the defendant concerning the location of the victim's body in violation of his right to counsel. The Court admitted the evidence on the grounds that a massive search that had previously been initiated would have inevitably resulted in the discovery of the body. It is not clear whether for the exception to apply the prosecution must establish that the authorities were already pursuing a lawful alternative method of investigation when the misconduct took place. See Meegan, supra note 45 at $1108, \mathrm{n} .688$.

Meegan, ibid. at 1109.

Chambers v. Maroney, 399 U.S. 42 (1970).

Milton v. Wainright, 407 U.S. 371 (1972).

Moore v. Illinois, 434 U.S. 220 (1977).

Arizona v. Fulminante, 111 S. Ct. 1246 (1991).

The justification for this kind of discretionary exclusion was eloquently expressed by Lord JusticeGeneral Cooper of the the High Court of Scotland in Lawrie v. Muir, [1950] S.C. 19 at 26-27, [1950] S.L.T. 37 at 39-40 [hereinafter Lawrie]:

From the standpoint of principle it seems to me that the law must strive to reconcile two highly important interests which are liable to come into conflict - (a) the interest of the citizen to be protected from illegal or irregular invasions of his liberties by the authorities, and (b) the interest of the State to secure that evidence bearing upon the commission of crime and necessary to enable justice to be done shall not be withheld from Courts of law on any merely formal or technical ground. Neither of these objects can be insisted upon to the uttermost. The protection of the citizen is primarily protection for the innocent citizen against unwarranted, wrongful and perhaps high-handed interference, and the common sanction is an action in damages. The protection is not intended as a protection for the guilty citizen against the efforts of the public prosecutor to vindicate the law. On the other hand, the interest of the State cannot be magnified to the point of causing all 
structure this discretion may therefore be highly relevant to the Canadian experience.

In deciding whether or not to exclude evidence obtained from an illegal search, for example, Scottish courts take into consideration the seriousness of the police impropriety, including whether the violation of accused's rights was deliberate or inadvertent, whether there was an urgent need to prevent the loss or destruction of evidence, the availability of lawful alternatives, and, in some cases, the seriousness of the offence. ${ }^{54}$ Similar factors are considered by courts in Australia and Ireland. ${ }^{5 s}$ These considerations are comparable to those Canadian courts take into account under the "seriousness of the violation" and "effect of excluding evidence" branches of the Collins test. ${ }^{56}$

There is some divergence in these jurisdictions, however, with respect to the manner in which the exclusionary discretion relates to confessional or self-incriminatory evidence. In Scotland, it seems that the nature of the evidence is one factor to be considered in the balancing process. In Lawrie v. Muir, Lord Justice-General Cooper stated:

Whether any given irregularity ought to be excused depends upon the nature of the irregularity and the circumstances under which it was committed. In particular, the case may bring into play the discretionary principle of faimess to the accused which has been developed so fully in our law in relation to the admission in evidence of confessions or admissions by a person suspected or charged with crime. 57

A similar position is taken in Australia. In Bunning v. Cross, ${ }^{58}$ the High Court noted that the discretion to exclude illegally obtained evidence related principally to real evidence, including articles found by search, electronic recordings, breath samples and fingerprint evidence. In such cases the Court is concerned with the balancing of public policy interests, of which fairness to the accused is one factor to be considered. ${ }^{59}$ This discretion, it was asserted, did not apply in the case of confession evidence. $^{60}$

This view was modified in $R$ v. Cleland.$^{61}$ In that case, the majority of the High Court determined that while the discretion to exclude confession evidence will usually be determined according to a test of "fairness," there remains a discretion to reject the

the safeguards for the protection of the citizen to vanish, and of offering a positive inducement to the authorities to proceed by irregular methods.

J.D. Heydon, supra note 13 at 608-10.

See D. McDonald, Legal Rights in the Canadian Charter of Rights and Freedoms, $2 \mathrm{~d}$ ed. (Toronto: Carswell, 1989) at 664-70.

For example, see Collins, supra note 3 at 212; $R$. v. Jacoy (1989), 66 C.R. (3d) 336 at 345, [1989], I W.W.R. 354 (S.C.C.) [hereinafter Jacoy].

Lawrie, supra note 53 at 27.

(1978), 141 C.L.R., 52 A.J.L.R. 561 [hereinafter Bunning].

Ibid. at 74-75 (C.L.R.), at 569 (A.J.L.R.).

Ibid.

(1982). 151 C.L.R. 1 at 9 (H.C.). 
evidence on the ground that it was obtained unlawfully. The Court concluded, however, that a voluntary confession which did not operate unfairly to the accused would rarely be excluded because of improper conduct by the authorities. Justice Dawson took a different view. He noted that the confession rule was originally conceived as a means to ensure reliability. Over time, the discretion came to incorporate a concern for police impropriety. ${ }^{62}$ With the development of the general discretion to exclude illegally obtained evidence, he argued, this latter aspect for the confession rule became superfluous. He stated:

\begin{abstract}
Considerations of faimess in the exercise of the older discretion relating to the exclusion of evidence of confessional statements must now be limited to faimess in the sense of fairness to the accused: whether it would be unfair to the accused to admit the evidence because of unreliability arising from the means by which, or the circumstances in which, it was procured. To view the situation otherwise would be to produce confusion because the newer discretion arising out of the decision in Bunning $v$. Cross, since it applies to all evidence, confessional or otherwise, necessarily encompasses the same policy considerations which may have hitherto played some part in the exercise of the discretion limited to evidence of confessional statements. Any function which the older discretion performed with regard to those policy considerations is now being performed by the application of the rule in Bunning v. Cross. ${ }^{63}$
\end{abstract}

In this view, the nature of the evidence that is improperly procured, that is, whether it is "real" or "self-incriminatory", is simply not relevant. ${ }^{64}$

In Ireland, this position is well-established. In The People v. O'Brien, the Supreme Court referred to fairness as "a dubious ground for exclusion" and asserted that emphasis should be placed "not so much on alleged fairness to the accused as on the public interest that the law should be observed even in the investigation of crime."165 In The People v. Lynch, ${ }^{66}$ the police obtained incriminatory statements from the accused after detaining him in violation of his constitutional rights. The Court concluded that the admissibility of the confession should be determined according to the same considerations that govern the admissibility of real evidence. ${ }^{67}$ In his reasons, Chief Justice O'Higgins noted that fairness concerns play a role in the discretion exercised in England and Scotland. In countries which have a written constitution which enshrines fundamental rights, he argued, different considerations apply. ${ }^{68}$ Justice Walsh added:

No valid distinction can be drawn between a statement or an admission obtained by reason of the constitutional deprivation of an accused's liberty and any other type of evidence so obtained. As has 
been so often pointed out, it is the protection and upholding of the Constitution which is the dominant consideration and not the preferment of one type of evidence over another. ${ }^{69}$

\section{CANADA: BEFORE THE CHARTER}

Canadian courts retained the strict inclusionary rule significantly longer than other common law jurisdictions. In $R$. v. Wray, ${ }^{70}$ the Supreme Court of Canada resoundingly rejected the view that a trial judge has the discretion to exclude evidence where he "considers that its admission would be unjust or unfair to the accused or calculated to bring the administration of justice into disrepute." ${ }^{71}$ Writing for the majority, Justice Martland interpreted the reference to "unfairness" in Kuruma to mean evidence whose probative worth was outweighed by its prejudicial effect. ${ }^{72} \mathrm{He}$ stated:

...the exercise of a discretion by the trial Judge arises only if the admission of the evidence would operate unfairly. The allowance of admissible evidence relevant to the issue before the Court and of substantial probative value may operate unfortunately for the accused, but not unfairly. It is only the allowance of evidence gravely prejudicial to the accused, the admissibility of which is tenuous, and whose probative force in relation to the main issue before the Court is trifling, which can be said to operate unfairly. ${ }^{73}$

The Court also put to rest any notion that the confession rule might incorporate a concern for anything other than reliability. It confirmed the validity of the "St. Lawrence rule", ${ }^{74}$ which mandates the admission of real evidence derived from an involuntary confession as well as any part of the confession "confirmed" by that evidence. $^{75}$ In dissent, Chief Justice Cartwright and Justice Spence agreed that the derivative real evidence should be admitted. They argued, however, that the portion of the confession confirmed by the real evidence should be excluded on the basis that it was unfairly compelled from the defendant, thus violating his right to silence. ${ }^{76}$

Ibid. at 84-85. As the arbitrary detention in this case was considered to be a "deliberate and conscious violation of the Constitution," and there was no "extraordinary excusing circumstance warranting admission," the evidence of the confession was excluded. Ibid. at 77. [1970] 4 C.C.C. 1, 11 D.L.R. (3d) 673 (S.C.C.) [hereinafter Wray].

This proposition had been espoused by Justice Aylesworth at the Court of Appeal in R. v. Wray, [1970] 3 C.C.C. 122 at 123 (O.C.A.).

Wray, supra note 70 at 17.

lbid.

R. v. St. Lawrence (1949), 93 C.C.C. 376,7 C.R. 464 (Ont. H.C.).

Wray, supra note 70 at 19.

Ibid. at 7 (per Chief Justice Cartwright) at 17 (per Justice Spence). The majority's refusal to recognize the self-incrimination principle meant that the exclusionary discretion in Canada was even narrower than that espoused in Kuruma and Sang. See supra note 12-27 and accompanying text. The Supreme Court reasserted its strict adherence to the exclusionary principle in Hogan v. The Queen, (1974) 48 D.L.R. (3d) 427 [hereinafter Hogan]. In Hogan, the Court refused to exclude evidence of a breathalyser test obtained in violation of section 2(c)(ii) of the Canadian Bill of Rights. In Rothman v. The Queen, (1981) 59 C.C.C. (2d) 30 [hereinafter Rothman], the Supreme Court confirmed that confession evidence could not be excluded on the basis that it was obtained improperly, even if the impropriety involved the use of an unfair trick. 
The Wray decision attracted considerable criticism." A number of law reform agencies responded by formally recommending the enactment of legislation which would give judges discretionary power of exclusion akin to that exercised in Scotland and Australia. ${ }^{78}$ Each of them also suggested the factors that a court should take into account in exercising this discretion. The Law Reform Commission of Canada, for example, described three broad criteria which should guide the exercise of the discretion. ${ }^{79}$ The first was the seriousness of the illegality. The question the court should ask itself, the Commission suggested, is whether the illegality "infringes a fundamental right or the principle of due process or ... contravenes a recognized constitutional right." Second, the court should consider the good or bad faith of the investigators. The third factor was the nature and seriousness of the offence. Here the court should be concerned with "consequences for society of freeing a person charged with committing an offence of a serious nature." ${ }^{80}$ Similar considerations were incorporated by the Commission into its Proposed Evidence Code ${ }^{81}$ and by the McDonald Commission in its report on Freedom and Security Under the Law. ${ }^{82}$ Notably, none of these recommendations for reform makes any distinction between real and self-incriminatory evidence, and apart from a casual reference in the Ouimet Report, none refer to the concept of "unfairness".

The aim of this section of the article has been to situate section 24(2) of the Charter in context: to trace its heritage and to discover its affinities with kindred legal traditions. In particular, I have endeavoured to unearth foundations for the concept of "unfairness" and the concomitant distinction between real and self-incriminatory evidence that has emerged in the Supreme Court's section 24(2) jurisprudence. In summary, it can be said that there are four general approaches to the exclusion of illegally obtained evidence. The first, which is the pre-Charter Canadian position, is that illegally obtained evidence, whether self-incriminatory or not, can never be

See McLellan \& Elman, supra note 25 at 228-29; B. Elman, "Returning to Wray: Some Recent Cases on Section 24 of the Charter" (1988) 26 Alta. L. Rev. 604 at 606-7.

See Law Reform Commission of Canada, Exclusion of Illegally Obtained Evidence, Study Paper No. 10 (Ottawr. Queen's Printer, 1974) at 24 [hereinafter Exclusion of Illegally Oblained Evidence]; Law Reform Commission of Canada, Report of Evidence (Ottawa: Queen's Printer, 1975) at 61; Ontario Law Reform Commission, Report on the Law of Evidence (Toronto: Ministry of the Attomey General, 1976) at 72; McDonald Commission, Freedom and Security Under Law, The Commission of Inquiry Concerning Certain Activities of the Royal Canadian Mounted Police, Second Report, vol. 2, 1981 at 1045 [hereinafter "McDonald Commission"].

Exclusion of Illegally Obtained Evidence, ibid. at 28. Even before Wray was decided, the Ouimet Committee suggested the adoption of an exclusionary discretion to be exercised in accordance with the following considerations:

(i) whether the violation of rights was wilful, or whether it occurred as a result of inadvertence, mistake, ignorance or error in judgment.

(ii) Whether there existed a situation of urgency in order to prevent the destruction or loss of evidence or other circumstance which in the particular case justified the action taken.

(iii) Whether the admission of the evidence in question would be unfair to the accused. See Report of the Canadian Committee on Corrections (Ottawa: Queen's Printer, 1969) at 74. Exclusion of Illegally Obtained Evidence, ibid. at 28.

Supra note 78, s. $15(2)$.

Sudra note 78 at $1046-47$. 
excluded for that reason alone. The second, the English approach, asserts that evidence cannot be excluded unless it is self-incriminatory evidence unfairly obtained from the accused. The third position, exemplified by Scotland, Australia and the Ouimet Committee, allows for exclusion all kinds of evidence on grounds of unfaimess or extrinsic policy. The fourth view, epitomized by Ireland, the United States and the other Canadian law reformers, is that exclusion of evidence should be based on a consideration of policy interests alone.

Canadian courts seem to have adopted an approach which corresponds with none of these alternatives. The Supreme Court of Canada has stated that evidence affecting fairness will almost always be excluded, whereas evidence affecting other policy interests will be excluded only in the most serious of cases. As I discuss in the following section, this distinction is difficult to justify both in theory and in practice.

\section{THE CHARTER JURISPRUDENCE}

\section{A. THE MEANING OF TRIAL FAIRNESS}

The notion that certain kinds of unconstitutionally obtained evidence should be more readily excluded under section 24(2) than others was first expressed by the Supreme Court in $R$ v. Therens. ${ }^{83}$ In his dissenting reasons, Justice Le Dain advanced the view that evidence obtained in violation of the right to counsel would be more likely to be excluded than evidence obtained from violations of other Charter rights. In considering the admission of evidence obtained from an unreasonable search, he asserted, the Court should be principally concerned with balancing the seriousness of the constitutional violation with the seriousness of the offence. Right to counsel violations, however, stood on a different footing:

The application of these factors to a denial of the right to counsel involves, in my view, a different balance because of the importance of that right in the administration of criminal justice. In my opinion, the right to counsel is of such fundamental importance that its denial in a criminal law context must prima facie discredit the administration of justice. That effect is not diminished but, if anything, increased by the relative seriousness of the possible criminal law liability. ${ }^{84}$

This special treatment for right to counsel violations received theoretical justification in Collins. ${ }^{85}$ In that case, the Court stated that it is not so much the significance of the right to counsel as the character of the evidence which generally results from such violations which is important. Evidence obtained after a violation of the right to counsel, the Court pronounced, will generally be excluded because admission of such evidence affects the "fairness of the trial." ${ }^{86}$ Justice Lamer explained:

(1985), 45 C.R. (3d) 97, [1985] I S.C.R. 613 [hereinafter Therens]. This was the first section 24(2) case decided by the Supreme Court.

Ibid. at 133. Le Dain J. went on to dissent on the basis that the police had relied in good faith on previous judicial authority.

Supra note 3.

Ibid. at 211. 
Real evidence that was obtained in a manner that violated the Charter will rarely operate unfairly for that reason alone. The real evidence existed irrespective of the violation of the Charter and its use does not render the trial unfair. However, the situation is very different with respect to cases where, after a violation of the Charter, the accused conscripted against himself through a confession or other evidence emanating from him. The use of such evidence would render the trial unfair, for it did not exist prior to the violation and it strikes at one of the fundamental tenets of a fair trial, the right against selfincrimination. Such evidence will generally arise in the context of an infringement of the right to counsel. Our decisions in Therens and Clarkson are illustrative of this. The use of self-incriminating evidence obtained following a denial of the right to counsel will generally go to the very fairness of the trial and should generally be excluded. ${ }^{87}$

By linking the pretrial right to silence with the privilege against testimonial selfincrimination, the Supreme Court greatly expanded the scope of these rights as they existed in pre-Charter law. ${ }^{88}$ Traditionally, the right to silence was not associated with the privilege against testimonial self-incrimination. ${ }^{89}$ It merely referred to the "the general right enjoyed in this country by anyone to do whatever one pleases, saying what one pleases or choosing not to say certain things, unless obliged to do otherwise by law." ${ }^{.90}$ The privilege against self-incrimination, in contrast, was limited to two very specific situations: the non-compellability of an accused at her own trial and the prohibition on the use of a witness' testimony in future proceedings against that person. ${ }^{91}$

In Charter jurisprudence, however, the pre-trial right to silence has been interpreted to incorporate the privilege against self-incrimination. ${ }^{92}$ The Supreme Court has recognized that both rights are based on the same principle: that an accused person has no obligation to provide evidence against himself, that he has a right to choose whether or not he will make a statement. ${ }^{93}$ It only makes sense, therefore, for the accused to be accorded the same right of choice at both phases of the criminal justice process. As Justice McLachlin noted in $R$. v. Hebert, "[t]he protection conferred by a legal system

Ibid. (Citations omitted).

See Jobson, supra note 2 at 344.

See R. Delisle, "Woolley: Finding Keys in the Distinction Between Statements and Real Evidence" (1988) 63 C.R. (3d) 347 at $347-8$.

Rothman, supra note 76 at 140 , per Justice Lamer.

E. Ratushny, Self-Incrimination in the Canadian Criminal Process (Toronto: Carswell, 1979) at 92. These rights are enshrined in sections $11(\mathrm{c})$ and 13 of the Charter respectively.

In this sense, the view that the Supreme Court takes of unfairness is broadly consistent with the view of the majority of the Law Lords in Sang, i.e. one which encompasses not only court room unfairness but also self-incrimination unfairness. A minority of their Lordships argued, as did the majority of the Supreme Court of Canada in Wray, that unfaimess in the way evidence was obtained could not have an adverse effect on the faimess of the trial itself. This position confines the scope of fairness to reliability or prejudice concerns. See supra notes $21-27$ and accompanying text.

R. v. Hébert (1990), 77 C.R. (3d) 145 at 181, 57 C.C.C. (3d) 1, [1990] 2 S.C.R. 151 [hereinafter Hébert]. In this case the right to silence was held to be a principle of fundamental justice protected by section 7 of the Charter. Though Hébert was decided more than three years after the decision in Collins, the Court's interpretation of the right to counsel in Collins implicitly encompasses the notion of the right to silence. See also Clarkson v. $R$. (1986), 50 C.R. (3d) 289 at 301-3, 25 C.C.C. (3d) 207, 26 D.L.R. (4th) 493, [1986] I S.C.R. 383. 
which grants the accused immunity from incriminating himself at trial but offers no protection with respect to pre-trial statements would be illusory." 94

\section{B. WHAT KIND OF EVIDENCE AFFECTS THE FAIRNESS OF THE TRIAL?}

In the context of section $24(2)$ determinations, this newly formulated conception of the right to silence has become a kind of "superright", fusing elements of the section 10 (b) right to counsel with the common law right to silence and privilege against selfincrimination. In the Supreme Court's view, whether or not the admission evidence affects the fairness of the trial depends on whether the evidence was obtained through a transgression of this generalized right to silence. As I have discussed, this will occur "where, after a violation of the Charter, the accused is conscripted against himself through a confession or other evidence emanating from him." 95

In practice, the use of this test has been problematic. Beyond the paradigmatic case of confessions, it has proved to be exceedingly difficult to determine exactly what kinds of evidence will affect the fairness of the trial. In Collins, for example, the Court retrospectively explained Therens ${ }^{96}$ as an instance where evidence was excluded because of its self-incriminatory nature. ${ }^{97}$ Therens was a case in which breath samples were obtained after a violation of the accused's right to counsel..$^{98}$ In Collins itself, evidence of illegal drugs was obtained after an unreasonable search which involved grabbing the accused by the throat and pushing her to the ground. The heroin recovered from the accused was characterized as real evidence; its admission in the proceedings, the Court concluded, would not render the trial unfair. ${ }^{99}$

How can these circumstances be distinguished? Arguably, in both cases the accused was "conscripted" against herself. Indeed, the "conscription" that took place in Collins was doubtless more intrusive than the breathalyser test in Therens. Certainly, the evidence in Collins did not "emanate" from the body of the accused in the same way the Therens breath sample did. It is far from clear, however, that this is a meaningful distinction. In both cases, the evidence existed in some form prior to the violation. And in each, the breach of the Charter right served to make the evidence accessible to the police. $^{100}$ In other words, if not for the violation, the authorities would not have been able to obtain the evidence. What could be more unfair than the admission of evidence that the police could not have obtained but for the violation of an individual's constitutional rights?

9 Ibid.

95 Collins, supra note 3 at 211.

\% Supra note 83.

97 Collins, supra note 3 at 211 . See also Jacoy, supra note 56 at $345 ; R$ v. Simmons (1988), 66 C.R. 297 at 326, 45 C.C.C. (3d) 296, 55 D.L.R. (4th) 673, [1988] 2 S.C.R. 495 [hereinafter Simmons]. Supra note 83. See also Rahn v. R. (1985), 45 C.R. (3d) 134, [1985] I S.C.R. 659 [hereinafter Rahn]; Trask v. $R$. (1985), 45 C.R. (3d) 137, [1985] I S.C.R. 655 [hereinafter Trask]. 
The analytical frailty of the real/self-incriminatory evidence distinction became even more apparent in subsequent cases. In a series of decisions involving illegally obtained blood samples, for instance, the Supreme Court has avoided determining definitively whether the use of such evidence affects the fairness of the trial. ${ }^{101}$ In $R$. v. Pohoretsky, the Court noted that the effect of the police's failure to obtain consent to obtain the blood sample was to "conscript the accused against himself." ${ }^{102}$ The Court also determined that the violation was very serious, however, and it is difficult to discern from the Court's terse reasons whether trial fairness was considered as a grounds for exclusion. ${ }^{103}$ In $R$. v. Dyment, ${ }^{104}$ the Court did not refer to the trial fairness rationale, and based its decision to exclude the evidence exclusively on the seriousness of the violation. In $R$. v. Dersch, the majority of the Court again failed to deal with the trial fairness issue, preferring to ground its decision on the seriousness of the violation by the police in taking advantage of "improper conduct by the [accused's] doctors in taking the blood samples contrary to the specific instructions of the patient." 105

In each of these cases, the Court seemed most concerned with the privacy interests of the accused. The Court recognized that the use of improperly obtained bodily samples represented a serious invasion of the accused's bodily integrity. In each case, the Court pointed out that breaches of the confidentiality of the doctor-patient relationship and of hospital records imperil the privacy of all Canadians. ${ }^{106}$ As Justice La Forest warned in Dyment, the free flow of information between police and doctors threatens the trust and confidence of the public in the administration of the health care system. ${ }^{107}$

The logic of the Collins "bodily emanation" test, however, makes it difficult to differentiate the unconstitutional seizure of a blood sample from the unconstitutional taking of a breath sample. Some commentators have asserted that blood samples, as well as other bodily samples obtained from "non-participatory investigative techniques"

In $R$ v. Brick (1989), 19 M.V.R. (2d) 158, the Alberta Court of Appeal held that blood samples are real evidence and do thus not invoke trial faimess concerns. The Ontario Court of Appeal has reached the opposite conclusion: $R$. v. Pavel (1989), 19 M.V.R. (2d) 294 at 312, 74 C.R. (3d) 195, 53 C.C.C. (3d) 296,36 O.A.C. 328. (1987), 58 C.R. (3d) 113 at 116 [hereinafter Pohoretsky].

It is the view of John Sopinka that the blood samples in Pohoretsky were excluded exclusively on the basis of the seriousness rationale. Sopinka et al., supra note 11 at 404 . This position is belied, however, by the Court's explicit reference to self-incrimination. (1988), 66 C.R. (3d) 348 at 367-9 (S.C.C.) [hereinafter Dyment].

(1993), 25 C.R. (4th) 88 at 96, 158 N.R. 375, [1993] 3 S.C.R. 768 [hereinafter Dersch]. In a separate opinion, Justice L'Heureux-Dube' (Justice Gonthier concurring) argued that the faimess of the trial would not be implicated in this case as the evidence could have been discovered lawfully and that the faimess of the trial was thus not adversely affected. Ibid. at 97-99. For a discussion of this principle of "discoverability", see infra notes 134-168 and accompanying text. Notably, L'Heureux-Dube J. determined that the discoverability of the evidence was not determinative of the issue in this case, and she went on to exclude the evidence on the same basis as the majority. Justice Major), at 100 (per Justice L'Heureux-Dubé). 
should be considered real evidence. Such evidence, it is argued, "exists notwithstanding any Charter violation, and is not created by the accused against whom it is adduced." ${ }^{108}$ A more sophisticated version of this argument distinguishes between samples that are obtained directly by the state authorities and samples that are acquired from independent third parties. Under this theory, fairness is not compromised where the blood is "separated" from the accused into seizable samples without the involvement of a government agent because the sample cannot be said to have been "conscripted" from the accused. ${ }^{109}$ This approach was advocated by Justice L'Heureux-Dubé in her concurring opinion in Dersch, ${ }^{110}$ and was endorsed by a majority of the Court in $R$. v. Colarusso."' In Colarusso, a blood sample which was obtained by hospital personnel for medical purposes was later turned over to an investigating coroner. A bare majority of the Court concluded that the subsequent appropriation of this evidence by the police constituted an unreasonable seizure. The Court noted, however, that "the coercive powers of the state played no role in creating the sample which was ultimately used to incriminate the appellant." ${ }^{112}$ Accordingly, the evidence was characterized as real and not self-incriminatory.

Distinguishing Therens from the blood sample cases by either the extent of the accused's participation or the directness of the police's involvement in the acquisition of the evidence is formalistic. It seems somewhat fallacious to say that an accused was "conscripted" where she is compelled to blow into a breathalyser, but not where he is forced to submit to a blood test. Similarly, whether or not a blood sample was obtained directly or indirectly makes little difference to the accused against whom the evidence is proffered at trial. ${ }^{113}$ The use of the real/self-incriminatory evidence distinction in these cases confounds the issues that are at stake. In all of these situations, the unfaimess stems not from the nature of the evidence, but from the state's attempt to take advantage of its own unconstitutional actions.

Like evidence of bodily samples, electronic recordings are also difficult to characterize as distinctly real or self-incriminatory. In $R$. v. Duarte, ${ }^{114} R$. v. Wiggins ${ }^{115}$ and $R$. v. Wong, ${ }^{116}$ the Supreme Court considered the use of audio or video recordings made by the police in violation of the section 8 right to be free from

10 Sopinka et al., supra note 11 at 405.

109 J. Watson, "Blood Samples: Are They Real or Not?" (1990) 2 J.M.V.L. 173 at 174.

$110 \quad$ Supra note 105 at $98-99$.

III (1994), 26 C.R. (4th) 289 at 316-17, 87 C.C.C. (3d) 193 at 230-31 [hereinafter Colarusso].

$112 \quad$ Ibid. at 316-17.

113 In Colarusso, the Court seemed to suggest that the accused's consent to the taking of the blood sample (for medical purposes only) somehow distinguished the case from Pohoretsky, Dyment and Dersch, where no such consent was obtained. In the former case, Justice La Forest averred, "the samples were already in existence prior to any seizure by the coroner or the police officers." Ibid. at 316. Only in Pohorestky, however, did the police actually participate in the initial taking of the sample. In all of the other cases the samples existed as discrete entities before state authorities became involved.

114 (1990), (sub. nom. $R$ v. Sanelli) 74 C.R. (3d) 281,53 C.C.C. (3d) I, [1990] I S.C.R. 30 [hereinafter Duarte].

115 (1990), 74 C.R. (3d) 311, 53 C.C.C. (3d) 476, [1990] 1 S.C.R. 62.

116 (1990), 1 C.R. (4th) 1, 60 C.C.C. (3d) 460 (S.C.C.) [hereinafter Wong]. 
unreasonable searches and seizures. Though such recordings might themselves be considered "real" evidence, the incriminatory statements or activities which formed their content clearly "emanated from the accused." 117 Unfortunately, the Court failed to specifically address the nature of the evidence in any of these cases. It seems implicit in the Court's decisions, however, that the Court did not consider the evidence to be self-incriminatory. In deciding to admit the evidence in all cases, Justice La Forest focused on the good faith of the investigators and the seriousness of the offenses in question. ${ }^{118}$ The Court had pointed out in Collins that, where trial fairness is affected, the seriousness of the offence will militate in favour of exclusion, not admission. ${ }^{119}$

In his academic capacity, Justice Sopinka has argued that electronic recordings should be characterized as real evidence. ${ }^{120}$ Discussing the Duarte case, he argues that the Charter violation did not cause the "creation" of the evidence. The accused's statements, according to this logic, had a discrete existence and "existed apart altogether from the $\mathrm{s.} 8$ violation (the taping of the statements)." ${ }^{121}$ In her dissenting opinion in Wong, Justice Wilson took the opposite position. ${ }^{122}$ She asserted that the videotape evidence was brought into existence by the Charter violation, and was thus analogous to a confession. The evidence did emanate from the accused, she noted, and the participation of accused was required in order to create it. As in the case of bodily samples, it seems that this kind of evidence is equivocal in terms of the real/selfincriminatory evidence distinction. ${ }^{123}$

Another form of evidence which reflects the indeterminacy of the Collins distinction was considered in $R$. v. Ross. ${ }^{124}$ That case involved the use of evidence derived from an identification line-up conducted in violation of the accused's right to counsel. In finding that this evidence would affect the faimess of the trial, the Court seemed to add a gloss to the "bodily emanation" test of Collins. Writing for the majority, Justice Lamer stated that "the use of any evidence that could not have been obtained but for the participation of the accused in the construction of the evidence for the purposes of trial would tend to render the trial process unfair."125 Justice Lamer noted that while a person's identity may generally be considered pre-existing "real evidence," by taking part in a line-up without being advised of their rights, the defendants were forced to participate in the construction of self-incriminatory evidence. ${ }^{126}$ Since the line-up evidence could not have been obtained without the defendants' participation, its use would detrimentally affect the fairness of the trial.

See D. Paciocco, "The Judicial Repeal of s. 24(2) and the Development of Canadian Exclusionary Rule" (1990) 32 Crim. L.Q. 326 at 360-1.

Duarte, supra note 114 at 301; Wong, supra note 116 at 19.

See Collins, supra note 3 at 212.

Sopinka et al., supra note 11 at $409-10$.

Ibid.

Supra note 116 at 26.

See T. Quigley \& E. Colvin, "Developments in Criminal Law and Procedure: The 1990-91 Term" (1992) 3 Sup. Ct. L. Rev. (2d) 121 at 182.

(1989), (sub nom. R. v. Leclair) 67 C.R. (3d) 209 (S.C.C.) [hereinafter Ross].

Ibid. at 220-1.

Ibid. at 221. 
Surprisingly, the Ross Court failed to discuss an earlier Supreme Court decision involving line-up evidence. In $R$. v. Marcouxx, ${ }^{127}$ a pre-Charter case, the Court held that the admission of line-up evidence did not violate the accused's privilege against self-incrimination. Justice Dickson stated that the right to reasonably compel an accused to take part in a line-up was an incident of police powers of arrest and investigation. Participation in a line-up, he argued, is not analogous to a confession and is "no more subject to objection than compelling the accused to exhibit his person for observation by a prosecution witness during a trial." ${ }^{128}$ In her dissenting opinion in Ross, Justice L'Heureux-Dube' argued that the identity of the accused and the perceptions of witnesses preexisted the denial of the right to counsel. ${ }^{129}$ Such evidence, she asserted, came into being when the accused were seen committing the crime and cannot be said to have "emanated" from the accused. Again, it seems that the distinction between "constructed" and "pre-existing" evidence is unhelpful here. It is arbitrary to maintain that evidence of identity obtained from a line-up affects the fairness of the trial, whereas other evidence of identity does not. ${ }^{130}$

Distinguishing between self-incriminatory and real evidence is an exercise in reification; it attempts to convert an abstract, theoretical construct into a entity with a natural or immanent essence. If the right to silence is to be interpreted to mean more than the right not to make incriminatory statements, then it makes little sense to discriminate between evidence that has somehow been "created" by the violation or which "emanates" from an accused and evidence which has some preexisting, tangible presence. The Collins distinction is unworkable because it fails to recognize that it is the effect of the evidence, and not its inherent "nature," which implicates the fairness interests of the accused.

Tim Quigley and Eric Colvin have argued that the decision whether to admit or exclude unconstitutionally obtained evidence should be grounded by a consideration of the values inherent in the Charter. ${ }^{131}$ The principle of adjudicative faimess demands that accused persons be treated equally. Individuals should not be disadvantaged because they are less able to protect their interests than others. ${ }^{132}$ As Quigley and Colvin point out, "[t]hose who are less well-equipped to handle themselves in the criminal process are less well-equipped to prevent the discovery of real evidence as well as to restrain themselves from self-incrimination." ${ }^{133}$ From the perspective of equality, the important distinction is between evidence that would not have been obtained without the constitutional violation and evidence that would have been available in any event. If the state obtains incriminatory evidence which it would not have acquired had a Charter violation not occurred, then the accused is placed in a

$128 \quad$ Ibid. at 7 (C.C.C.).

129 Supra note 124 at $223-4$.

130 See T. Quigley \& E. Colvin, "Developments in Criminal Law and Procedure: The 1988-89 Term" (1990) 1 Sup. Ct. L. Rev. (2d) 187 at 233.

131 Ibid. at 236.

$132 \mathrm{Ibid}$. at 232.

133 Ibid. 
worse position than she would have been had the investigative authorities complied with the law. ${ }^{134}$

This approach to trial fairness, which has been termed a test of "discoverability" by some commentators, considers whether or not the evidence would have been discovered but for the Charter violation. ${ }^{135}$ It is similar to the American doctrine of inevitable discovery in that it asks whether the evidence would have been obtained notwithstanding the infringement of the accused's rights. ${ }^{136}$ In the next section, I will examine some recent decisions from the Supreme Court of Canada which may herald a tentative move toward such an approach.

\section{REAL EVIDENCE AND TRIAL FAIRNESS}

The roots of the "discoverability" approach to section 24(2) can be traced to dicta by Justice Lamer in Collins and Ross. In discussing the factors relating to the fairness of the trial in Collins, Justice Lamer stated that "[i]t may also be relevant, in certain circumstances, that the evidence would have been obtained in any event without the violation of the Charter". ${ }^{137}$ In Ross, he noted that trial fairness would be affected by "the use of any evidence that could not have been obtained but for the participation of the accused in the construction of the evidence." 138 In subsequent decisions, the Court has seized upon these statements to put forth the view that real evidence may, in certain limited circumstances, affect the fairness of the trial.

In $R$. v. Black, the Supreme Court intimated that discoverability might be a factor in determining whether the admission of real evidence might affect trial fairness. ${ }^{139}$ The accused, after a violation of her right to counsel, provided an inculpatory statement which revealed the location of the murder weapon, a knife. She was later led by the police to the scene of the crime where she recovered the knife for them. The Court excluded the confession, but admitted the knife on the grounds that it was real evidence and did not therefore affect the fairness of the trial. Following the test set out in Ross, the Court ruled that while the police obtained the evidence as a consequence of the Charter violation, the evidence did not come into existence as a result of the accused's participation in the construction of the evidence. ${ }^{140}$ An additional reason for admitting the evidence, the Court stated, was the fact that "the police would have conducted a

This conception of fairness has been advanced by a number of scholars. In addition to Quigley \& Colvin, ibid., see Delisle, supra note 89 at 348-9; R.J. Delisle, "Collins: An Unjustified Distinction" (1987) 56 C.R. (3d) 216; R.J. Delisle, "The Exclusion of Evidence Obtained Contrary to the Charter: Where Are We Now?" (1989) 67 C.R. 288 at 292; K. Jull, "Exclusion of Evidence and the Beast of Burden" (1988) 30 Crim. L.Q. 178 at 183-4; M.T. MacCrimmon, "Developments in the Law of Evidence: The 1986-87 Term" (1988) 10 Sup. Ct. L. Rev. 225 at 242-51. C. Davison, "Connecting Real Evidence and Trial Fairness: The Doctrine of 'Discoverability'" (1993) 35 Crim. L.Q. 493 at 494.

136 See supra note 47 and accompanying text.

137 Supra note 3 at 212.

138 Supra note 124 at $220-1$.

139 (1989), 70 C.R. (3d) 97 at 116-7, 50 C.C.C. (3d) 1, [1989] 2 S.C.R. 138. 
search of the appellant's apartment with or without her assistance and that such a search would have uncovered the knife."141

The concept of discoverability also was also addressed by Justice La Forest in Thomson Newspapers Ltd. v. Canada (Director of Investigation and Research). ${ }^{142}$ This case involved a consideration of whether real evidence derived from compelled testimony could be used by the state against the accused in subsequent proceedings. In the course of making an analogy to the Court's section 24(2) jurisprudence, Justice La Forest explained that the Collins distinction between real and self-incriminatory evidence was based on a version of the discoverability theory. He stated:

\begin{abstract}
A breach of the Charter that forces the eventual accused to create evidence necessarily has the effect of providing the Crown with evidence it would not otherwise have had. It follows that the strength of its case against the accused is necessarily enhanced as a result of the breach...In contrast, where the effect of a breach of the Charter is merely to locate or identify already existing evidence, the ultimate strength of the Crown's case is not necessarily strengthened in this way. The fact that the evidence already existed means that it could have been discovered anyway. Where this is the case, the accused is not forced to confront any evidence at trial that he would not have been forced to confront if his Charter rights had been respected. ${ }^{143}$
\end{abstract}

While Justice La Forest maintained that real evidence located through a Charter violation would not generally affect trial faimess, he noted that there may be circumstances where derivative real evidence was so concealed or inaccessible that it could not have been discovered without the involvement of the accused. ${ }^{144}$ In such situations the prosecution's case would be strengthened by the use of the illegally obtained evidence and the fairness of the trial would thus be compromised. ${ }^{145}$

The Supreme Court had another opportunity to deal with the discoverability principle in $R$ v. Wise. ${ }^{146}$ In that case, the Court considered whether to exclude evidence of the movements of a car obtained from an electronic tracking device. Unfortunately, the majority seemed to decide the case on the basis of a rather mechanistic application of the Collins distinction between real and self-incriminatory evidence. The evidence could not be considered conscriptive, the Court stated, because the accused was not compelled or enticed to drive the car along predetermined routes. ${ }^{147}$ The majority also made reference to Justice La Forest's comments in Thomson, stating cursorily that evidence of the car's movements was "not undiscoverable" by other means. ${ }^{148}$ In dissent,

Ibid. at 117.

(1990), 76 C.R. (3d) 129, 54 C.C.C. (3d) 417 (S.C.C.) [hereinafter Thomson].

Ibid. at 232-3 (emphasis added). See also $R$ v. Smith (1991), 4 C.R. (4th) 125 at 141 (S.C.C.), where Justice McLachlin noted that there are "two related factors which may make the statement unfair: (1) the fact that the statement is self-incriminating; and (2) the fact that the evidence would not have been available but for the breach."

lbid. at 234-5.

Ibid.

(1992), 11 C.R. (4th) 253, 70 C.C.C. (3d) 193, [1992] 1 S.C.R. 527 [hereinafter Wise].

Jbid. at 265-6.

Jbid. at 267. 
Justice La Forest asserted that the Collins distinction was not helpful in this kind of situation. Disagreeing with the majority's analysis of the discoverability issue, he argued that the fairness of the trial would be compromised as the state was placed in a more advantageous position than it would have been had the violation not taken place. $^{149}$

The Supreme Court came close to adopting a discoverability theory of trial fairness in $R$. v. Mellenthin. ${ }^{150}$ In that case, the accused was detained at a check stop and questioned about the contents of a bag lying on the passenger seat of his car. He presented the bag to the police officer who noticed it contained glass vials commonly used to store narcotics. The police officer arrested the accused and conducted a further search of the car which produced significant quantities of drugs. The Court determined that the questioning and subsequent search were conducted without reasonable and probable grounds and constituted a violation of section 8 of the Charter. ${ }^{151}$ For a unanimous Court, Justice Cory determined that though the evidence in this case was clearly "real", it should nevertheless be excluded on the basis that its admission would affect the fairness of the trial. After referring extensively to the discoverability analysis in Thomson, he stated that "the trial judge could certainly not be said to have acted unreasonably in concluding that the evidence (the marijuana) would not have been discovered without the compelled testimony (the search) of the appellant."152 The Court noted that the use of evidence obtained in this manner "would adversely and unfairly affect the trial process and most surely bring the administration of justice into disrepute. ${ }^{1153}$

Although the Court found support for its conclusion in the comments of Justice La Forest in Thomson, the decision in Mellenthin seems to go much further. ${ }^{154}$ Justice La Forest had stated in Thomson that fairness will generally be affected only by evidence that was created by the participation of the accused in the investigation. The use of real evidence, he argued will only be unfair if it was so inaccessible that it could not have been discovered without the involvement of the accused. In Mellenthin, the drugs were not well-hidden, and the police certainly could have discovered them without the participation of the accused. What the Court in Mellenthin tacitly endorses is a wider principle of discoverability, i.e. that it is unfair to admit evidence that would not have been discovered but for the violation of the accused's constitutional rights. ${ }^{\text {.s5 }}$

Ibid. at 274

(1992), 16 C.R. (4th) 273, [1993] 1 W.W.R. 193, 144 N.R. 50 (S.C.C.) [hereinafter Mellenthin]. Ibid. at 279-81.

Ibid. at 284.

Ibid. at 284-5.

See R.J. Delisle, "Mellenthin: Changing the Collins Test" (1992) 16 C.R. (4th) 286 at 290.

The discoverability doctrine was explicitly adopted by the Alberta Court of Appeal in $R$ v. Meddoui (1990), 2 C.R. (4th) 316, 61 C.C.C. (3d) 345, [1991] 2 W.W.R. 289, application for leave to appeal to S.C.C. quashed 69 C.C.C. (3d) vi, 6 C.R.R. 192n, 137 N.R. 389n [hereinafter Meddoui]. In that case, the police obtained evidence of a key fob after a violation of the accused's right to be secure from unreasonable search or seizure. Justice Kerans stated that the faimess of the trial will be affected where the accused can establish that "the state, but for the infringement of the rights of the accused, would not have discovered the preexisting real evidence." According to Justice Kerans "the conscription of the accused to testify against himself is only the paradigm,
} 
The degree of the accused's "participation" in the discovery of the evidence is not relevant to this determination. As pointed out by Justice Kerans in Meddoui, any attempt to discriminate between cases based on the personal involvement of the accused is bound to produce absurd results. ${ }^{156}$ Does it make sense to say that an accused's right against self-incrimination is violated when she is forced to participate in an identification line-up but not when blood samples are taken against her will? ${ }^{157}$ It is logical to maintain that an accused is compelled to produce incriminating evidence when he is asked to take a breathalyser test, but not when he is subjected to an intrusive or violent body search? ${ }^{158}$

It should be noted that the Mellenthin Court did not explicitly adopt the discoverability theory, and it did not explicitly abandon the requirement set out in Thomson that the accused must somehow be involved in the discovery of the evidence in order for the fairness of the trial to be affected. ${ }^{159}$ The discoverability issue was explicitly addressed by the majority in Colarusso, however. Reiterating his comments in Wise, Justice La Forest asserted that the fact that the blood sample "could have been discovered in any event" was an important consideration weighing in favour of inclusion. ${ }^{160} \mathrm{He}$ noted that by the time the coroner intervened and seized the samples, the police had already arrested the accused and had ample grounds to demand a breath sample or another blood sample or to obtain a warrant for the sample that the coroner had previously taken.

Despite these encouraging forays into discoverability analysis, it is unclear how far the Supreme Court's support for the concept will go. Unfortunately, it is apparent that the Court is still very much committed to the Collins distinction between real and incriminatory evidence. ${ }^{161}$ In a number of recent decisions, the Court has summarily dismissed the notion that real evidence obtained through the violation of Charter rights

the perfect example, of the operation of the troubling thought that the state might somehow take advantage of its violation of the constitutional rights of the accused to bolster its case against him." Ibid. at 336 .

Ibid. at 336.

Compare Ross, supra note 124, with Dyment, supra note 104, and Dersch, supra note 105. Compare Therens, supra note 83; Rahn, supra note 98; and Trask, supra note 98, with Collins, supra note 3; Jacoy, supra note 56; and Simmons, supra note 97 at 495 . Indeed, while the unconstitutional breathalyser demand clearly involves a relatively serious infringement on the accused's privacy, it would seem to be only a minor infringement of his right to a fair trial. In Therens, had the accused had been informed of his right to counsel and he chosen to exercise that right, his lawyer would have advised him that so long as the police followed proper procedures, he must either blow or be charged with refusal. From the accused's perspective, the outcome of the trial would likely have been similar in either case.

The discoverability doctrine was explicitly adopted by a concurring minority in Dersch. The majority in that case, however, declined to deal with the issue. Supra note 105 at 97-99 (per Justice L'Heureux-Dubé, Justice Gonthier concurring).

Supra note 111 at 317.

At least one current Supreme Court Justice, Justice John Sopinka, has in his academic capacity asserted that the admission of real evidence can never affect the faimess of the trial. See Sopinka, et al., supra note 11 at 407. 
might affect trial fairness. In $R$. v. Grant, ${ }^{162}$ for example, the Court considered the admission of evidence of illegal drugs that had been obtained after an unconstitutional perimeter search. The Court denied that the admission of the evidence would be unfair, and admitted the evidence on the basis of good faith reliance by the police on statutory authority. Grant was distinguished from the Court's earlier decision in $R$ v. Kokesch ${ }^{163}$ on the basis that in the latter case the police lacked reasonable and probable grounds for the search.

Yet these cases could be rationalized with the discoverability principle. Arguably, the absence of reasonable and probable grounds in Kokesch rendered the evidence undiscoverable. In Grant and its companion cases, the existence of reasonable and probable grounds suggests that the evidence could have been obtained without the Charter violation. Indeed, many of the cases in which the court has considered the admissibility of real evidence can be retrospectively explained by the discoverability doctrine. In Duarte, for example, the existence of reasonable and probable grounds was again mentioned as a justification for the admission of an audio-visual recording. ${ }^{164}$ The Court noted that had the police properly understood the law, they could have obtained the proper authorization to intercept the communication in question. As in Grant, this evidence was discoverable in the sense that it could have been obtained by lawful means. Conversely, a lack of reasonable and probable grounds was referred to in $R$. v. Greffe as a justification for excluding evidence obtained after a serious violation of the accused's right against unreasonable search and seizure. ${ }^{165}$

An even stronger case for the application of the discoverability approach could be made in the case of $R$ v. Strachan, ${ }^{166}$ where evidence of illicit drugs was obtained from a legal search. In the course of the search, the police violated the accused's right to counsel. The Court determined that there need not be a causal connection between the Charter violation and the obtaining of the evidence in order to trigger the operation of section 24(2). ${ }^{167}$ In such circumstances, however, it is clear that the evidence would have been discovered whether or not the accused's Charter rights were infringed. If evidence obtained in this manner is to be excluded, then it must be for reasons other than the trial fairness rationale. ${ }^{168}$ (1993), 84 C.C.C. (3d) 203, 157 N.R. 321 (S.C.C.) and $R$ v. Wiley (1993), 84 C.C.C. (3d) 161, 158 N.R. 321 (S.C.C.).

163 (1990), 1 C.R (4th) 62 (S.C.C.).

164 Supra note 114.

lis (1990), 75 C.R. (3d) 257, 55 C.C.C. (3d) 161, [1990] 1 S.C.R. 755.

$166 \quad[1989] 1$ W.W.R. 385 (S.C.C.).

ist Ibid. at 401-2.

168 See also R. v. DeBot (1989), 73 C.R. (3d) 129, 52 C.C.C. (3d) 193, [1989] 2 S.C.R. 1140 and Jacoy, supra note 56. These were also cases in which real evidence was obtained after a breach of section 10(b), but as a result of a legal search. The Court noted in both cases that the obtaining of the evidence was totally unrelated to the Charter violation. 


\section{ADMISSION NOTWITHSTANDING TRIAL UNFAIRNESS}

In Collins, the Supreme Court indicated that the admission of evidence affecting the fairness of the trial would tend to bring the administration of justice into disrepute, and that, subject to a consideration of other factors, such evidence should generally be excluded. ${ }^{169}$ Though there have been very few cases in which evidence affecting fairness has been admitted, ${ }^{170}$ it has until recently been thought that a consideration of other factors could result in the admission of such evidence. ${ }^{171}$ Until its ruling in $R$. v. Elshaw, ${ }^{172}$ the Court had always addressed the other Collins factors even where unfairness was found. In Elshaw, the Court took the view that evidence affecting trial fairness cannot be saved by resorting to the good faith of the police or any other factor implicating the seriousness of the violation. ${ }^{173}$

Don Stuart has argued that this dictum from Elshaw is misleading, and that the Court did not intend to propound a rule of automatic exclusion for unfair evidence. ${ }^{174}$ Given that the Court in Elshaw went on to consider the other Collins factors, this was not an unreasonable position. In Mellenthin, however, the Court clearly stated that "where the admission of the evidence would render the trial unfair there is no need to consider the other factors referred to in Collins." ${ }^{175}$

This development is regrettable because it further ossifies the distinction made in Collins between real and self-incriminatory evidence. I have argued in this article that this distinction is specious and that a better approach to fairness would consider whether the illegally obtained evidence would have been discovered notwithstanding the breach of the accused's constitutional rights. The Supreme Court's approach to trial fairness brings to light a broader issue, however. Assuming that the admission of certain kinds of evidence can be said to imperil the fairness of the trial, why is it that such evidence should be more readily excluded than evidence impinging upon other Charter values, such as privacy?

Section 24(2) provides that evidence should be excluded when its admission would have an adverse effect on the repute of the administration of justice. The Supreme

\section{Supra note 3 at 212 .}

Two exceptions are $R$ v. Tremblay (1987), 60 C.R. (3d) 59, 37 C.C.C. (3d) 565, [1987] 2 S.C.R. 435, and R. v. Mohl (1989), 69 C.R. (3d) 399, 47 C.C.C. (3d) 575, [1989] 5 W.W.R. 66, 95 N.R. 381, 77 Sask. R. 35, [1989] I S.C.R. 1389. In the former case, evidence of a breath sample was admitted on the basis that the violation had been provoked by the accused's belligerent and obstreperous behaviour. In the latter case, the Court again admitted breathalyser evidence which had been obtained from an accused who was too intoxicated to understand his rights at the time they were read to him. For an analysis of the rationales of these decisions, see Sopinka et al., supra note 11 at 407-9.

Stuart, supra note 2 at 398.

(1991), 7 C.R. (4th) 333, [1991] 3 S.C.R. 24 [hereinafter Elshaw].

Ibid. at 350. The Court reiterated this view in R. v. Broyles (1991), 9 C.R. (4th) 1, 68 C.C.C. (3d) 308, [1991] 3 S.C.R. 595. This position was originally expressed by Justice Sopinka in Hebert, supra note 93 at 167 . 
Court has stated that the purpose of excluding evidence under section 24(2) of the Charter is to preserve the integrity of the justice system. In Collins, Lamer J. stated:

Misconduct by the police in the investigatory process often has some effect on the repute of the administration of justice, but s. $\mathbf{2 4 ( 2 )}$ is not a remedy for police misconduct, requiring the exclusion of the evidence if, because of this misconduct, the administration of justice was brought into disrepute. Section 24(2) could well have been drafted in that way, but it was not. Rather, the drafters of the Charter decided to focus on the admission of evidence in the proceedings, and the purpose of s. 24(2) is to prevent having the administration of justice brought into further disrepute by the admission of the evidence in the proceedings. ${ }^{176}$

Is it true that the admission of evidence which implicates fairness concerns will more readily compromise judicial integrity than evidence obtained from a violation of privacy rights? More fundamentally, is it valid to make a distinction between fairness and privacy in the first place? David Galligan has argued that the right to silence, which undergirds the concern for fairness in Charter jurisprudence, is philosophically grounded on the right to privacy. ${ }^{177}$ The right to silence, according to Galligan, protects personal autonomy and identity. Privacy, he posits, can be represented as an expanding circle with individual personality at the centre: the closer an issue is to the core, the less likely it is to be outweighed by competing factors, such as the state's interest in crime control. Employing this analysis, an unfairly obtained confession would clearly violate the core of personal autonomy. Yet so might a compelled search of an individual's body cavities. Treating the former as an impingement of fairness and the latter as a violation of privacy mystifies the issues that are at stake. In both examples, the state makes an unjustified intrusion into the autonomy of one of its citizens.

If fairness and privacy are simply variations of the same general theme, it makes little sense to assert that evidence affecting fairness should be automatically or even presumptively excluded, whereas evidence affecting privacy should be prima facie

Supra note 3 at 208 (emphasis in original). See also R. v. Genest (1989), 45 C.C.C. (3d) 385 at 390, 67 C.R. (3d) 224, [1989] I S.C.R. 59. In adopting a justification for exclusion based on the integrity of the justice system, the Court followed the lead of the Law Reform Commission of Canada. In its 1974 Report, the Commission stated:

The State, like Caesar's wife, must be above suspicion and its courts must not lend their support even indirectly to disrespect for basic priorities. They must, as the justices of equity have said, "come to justice with clean hands." To do otherwise leaves the State in an untenable position. Having once guaranteed certain fundamental rights and encouraged respect for the law, the State could not permit the results of a violation of these rights to be used as evidence in the courts.

Supra note 78 at 23 . For discussions of the various rationales for the exclusion of illegally obtained evidence see D. Paciocco, supra note 117; P. Mirfield, "The Early Jurisprudence of Judicial Disrepute," (1988) 30 Crim. L.Q. 434 at 438-41. For a critique of the Supreme Court's rejection of the deterrence rationale see B. Elman, "Collins v. The Queen: Further Jurisprudence on Section 24(2) of the Charter" (1987) 25 Alta. L. Rev. 477 at 484-5. 
admissible. I believe this was implicitly recognized by Justice Kerans in Meddoui. He stated that discoverability was not determinative of the fairness question, and that if a judge finds that, but for the breach, the evidence would not have been discovered, he must go on to consider the other Collins factors. ${ }^{178}$ Conversely, evidence that would have been found in any event may still be excluded, if for example the violation of the Charter was serious. ${ }^{179}$

Courts, I submit, should not be concerned with formulating rules or presumptions for the exclusion or admission of different kinds of evidence. A section 24(2) determination is, in essence, a discretionary exercise. If the legal rights protected by the Charter are to be taken seriously, then arguably the only presumption that should apply is that evidence obtained in violation of those rights should not be admitted unless there is a justifiable reason for doing so. Whether or not such a presumption is adopted, the principles that courts employ to structure this discretion should reflect all the values that the Charter protects.

The discoverability test presents a coherent and comprehensible method of assessing the effect of admission on the fairness of the criminal justice process. ${ }^{180}$ It may also help to gauge the effect of the violation on the accused's privacy interests. If the evidence would have been obtained without any Charter infringement, then it is difficult to say that the accused's privacy interest in the evidence has been violated. The purpose of privacy rights is not defeated when the state acquires evidence that the accused can have no privacy interest in. ${ }^{181}$ Of course, the improper acquisition of discoverable evidence may encroach upon the accused's privacy in other ways. Other principles, such as the degree of intrusiveness of the accused's personal autonomy, may be useful in assessing the effect of admitting the evidence on these privacy interests. ${ }^{182}$ The point here is not to catalogue the various ways courts can address the circumstances surrounding the exclusion of evidence under section 24(2). Rather, it is simply to indicate that the decision to admit or exclude evidence must be grounded on a consideration of the interests the Charter was designed to protect.

Supra note 155 at $339-40$.

lbid. at 340.

There are, not surprisingly, a number of facets of the discoverability theory which cannot be fully addressed in this article. One is the question of the extent to which courts will be willing to engage in hypothetical inquiries to determine whether evidence was truly discoverable by lawful means. Another is the relationship between discoverability and the "seriousness of the violation" factors considered in the second stage of the Collins test. At the "fairness" phase of the test, the fact that evidence was discoverable by lawful methods counts towards its inclusion. In some circumstances, however, the fact that the police could have proceeded by lawful means will be a factor which aggravates the seriousness of the violation and will militate in favour of exclusion. This would mean that the same factor - the availability of alternative means of investigation - may work one way at one stage of the Collins test and the opposite way at another. See Davison, supra note 135 at 505-507.

See Quigley \& Colvin, supra note 130 at 237.

This principle is reflected in the Supreme Court's approach to the seriousness of the violation in search and seizure cases. The Court seems to have developed a sliding scale of increasing intrusiveness with respect to searches of a person's office, car, home, and body. For example, see Pohoretsky, supra note 102; Dyment, supra note 104, Wise, supra note 146; and Dersch, supra note 105. 


\section{CONCLUSIONS}

The inclusion of section 24(2) in the Charter has resulted in a profound change in the way courts deal with illegally obtained evidence. For the first time, Canadian courts have been propelled to exclude evidence because of the manner in which it was obtained. Yet paradoxically, the jurisprudence of the Supreme Court indicates that it is the nature of the evidence, and not the method of its acquisition, which is the prime consideration in the decision to exclude.

In deciding to approach section 24(2) determinations in this manner, the Supreme Court has followed a course which is unique in the common law world. No other jurisdiction with a general discretion to exclude illegally obtained evidence presumptively favours the exclusion of unfairly acquired evidence over other kinds of evidence. Though some jurisdictions approach the exclusion of confession evidence on a different basis than other evidence, they do not privilege "fairness" over other interests in the way Canadian courts do. In these countries, the exclusion of nonconfession evidence is determined according to the balancing of policy interests, of which unfaimess is only one factor to be considered.

Why has the Supreme Court of Canada taken this approach? Arguably, the focus on trial faimess reveals the extent to which the Court remains reluctant to embrace a more expansive, supervisory role over the criminal justice system. Instead of exerting its authority over the breadth of the entire process to ensure fair treatment and compliance with Charter values, the Court has focused its attention on factors affecting the faimess of the trial itself. In effect, the Court has elevated its concern for adjudicative fairness above consideration of the fairness of the criminal justice system as a whole. This result is unfortunate, because it may render individual Canadians more susceptible to invasions of their constitutional rights. 